\title{
Contemporary and futuristic perspectives on leadership practice in emerging countries contexts
}

CrossMark

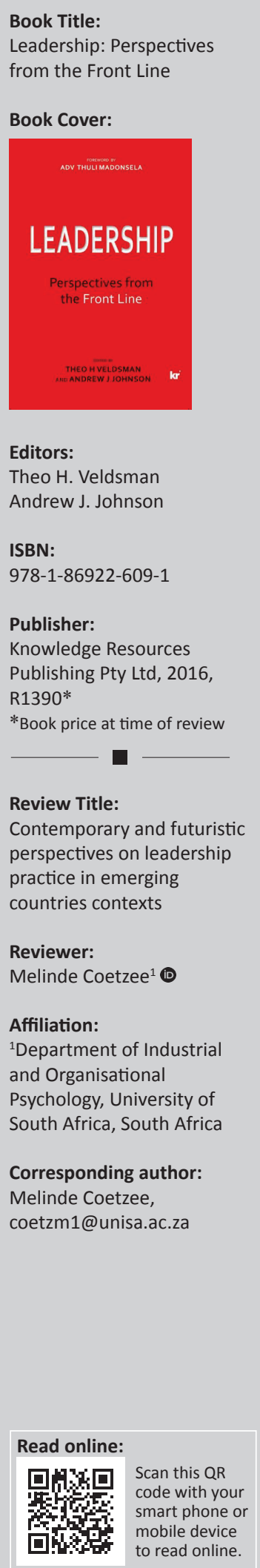

\section{Introduction}

The book, Leadership: Perspectives from the Front Line is a much welcomed addition to the leadership literature. The visionary perspective of leadership flowing from a realistic assessment of the present state and role of leadership through the integrated, holistic strategic leadership value chain framework (Veldsman \& Johnson, 2016, p. 3) is a novel contribution that adds a new dimension to the leadership literature. The themes addressed by the book deal with a broad spectrum of dimensions (covered across 56 chapters) highly relevant to leadership in the contemporary world of work and especially the emerging countries context. The book makes a call for 'better and different' leadership in a radically changing world that is in the throes of fundamental and radical transformation. The theme of leadership is presented from an 'integrated, holistic strategic leadership value chain perspective on the notion of leadership as a critical strategic capability and intervention' (Veldsman \& Johnson, 2016, p. 2). Leadership as a critical strategic capability is seen as a solution for making nations, societies, communities and organisations 'sustainably future-fit' (Veldsman \& Johnson, 2016, p. 1).

\section{General overview}

The theme and chapter contributions (56 chapters in total) address a comprehensive range of dimensions that are meaningfully and coherently presented from the total strategic leadership value chain framework: Section 1 (Setting the scene - 1 chapter), Section 2 (Ways of understanding leadership - 10 chapters), Section 3 (The unfolding leadership context - 12 chapters), Section 4 (Leadership excellence -2 chapters), Section 5 (Profiling tomorrow's leaders relative to the unfolding context -15 chapters), Section 6 (Leadership identification, growth and development 6 chapters), Section 7 (Leadership dynamics and transitions -3 chapters), Section 8 (Leadership wellbeing -3 chapters), Section 9 (Leadership outcomes and impact -1 chapter), Section 10 (Leadership stories -1 chapter), Section 11 (Leadership lament -1 chapter) and Section 12 (Looking ahead - 1 chapter).

Section 1 (Setting the scene) serves as introduction by outlining the total strategic leadership value chain framework and evaluating leadership as strategic organisational capability and intervention. Section 2 (Ways of understanding leadership) addresses themes such as the leadership landscape, appreciative leadership, neuroscience in leadership, action science, psychological profiling, Kegan's competing commitments, Arbinger's changing mindset, leadership psychodynamics, reauthoring leadership narratives and action learning. Section 3 (The unfolding leadership context) outlines themes relevant to the world of tomorrow and leadership challenges, demands, and requirements, school leadership, leading in the South African higher education context, public sector leadership, community leadership, sports leadership, leading professional firms, business leadership, political leadership, religion, spirituality and leadership, ecologically embedded leadership and leadership engagement with the context.

Section 4 (Leadership excellence) evaluates various dimensions of leadership and leadership excellence across cultural settings. Section 5 (Profiling tomorrow's leaders relative to the unfolding context) presents various perspectives on leadership brand modelling, authentic leadership, mindful leadership, virtuous leadership, wise leadership, spiritual leadership, ethical leadership, African leadership, women in leadership, multi-generational leadership, diversity leadership, change leadership, team leadership, entrepreneurial leadership and board leadership. Section 6 (Leadership identification, growth and development) explores leadership talent for an uncertain future, leadership assessment, business schools as hubs of leadership education,

How to cite this book review: Coetzee, M. (2017). Contemporary and futuristic perspectives on leadership practice in emerging countries contexts. SA Journal of Industrial Psychology/SA Tydskrif vir Bedryfsielkunde, 43(0), a1475. https://doi.org/10.4102/sajip.v43i0.1475 Copyright: @ 2017. The Authors. Licensee: AOSIS. This work is licensed under the Creative Commons Attribution License. 
leadership development principles, approaches, and processes, leadership coaching and corporate universities.

Section 7 (Leadership dynamics and transitions) discusses leadership flourishing and thriving, leadership identity and leadership transitions. Section 8 (Leadership wellbeing) explores leadership phenomena such as stress, burnout, derailment and resilience, toxic leadership in organisations and leadership maturity. Section 9 (Leadership outcomes and impact) evaluates leadership excellence measurement. Section 10 (Leadership stories) presents 15 narratives by leaders from various organisational settings. Section 11 (Leadership lament) outlines leadership by the well-known Johann Coetzee, and in Section 12 (Looking ahead), the editors (Andrew Johnson and Theo Veldsman) outline their futuristic view on leadership.

\section{Contribution and value added}

The book is a timely addition to the leadership literature and bridges the gap between current academic (research-based) and popular self-help leadership literature. The book is written from a unique framework (the strategic leadership value chain) and put into perspective for the Africanised multiculturally diverse organisational setting. The various chapter contributions speak across this total strategic leadership value chain (Veldsman \& Johnson, 2016, p. 3) to the current and foreseen complex dynamics imposed by the leadership demands and challenges faced by organisations in emerging countries contexts. The value added of the book lies in its unique niche alluding to leadership from a holistic and strategic stance at the front line (real-life practice) from a well-grounded, research evidence-based perspective. Although the book does not represent ground-breaking research, its strength lies in presenting the theme of leadership from a novel, interesting and thought-provoking viewpoint that represents cutting edge, 'present-into-the-future' and 'future-into-the-present', thinking, insights and informed views presented by the various authors across the total strategic leadership value chain. Anchoring the chapter contributions and leadership themes in a well-reasoned holistic total strategic leadership value chain framework is new and original. In addition, the real-life practical applications and narratives are novel in bringing leadership at the front line to life. The knowledge gained from the emerging countries perspectives adds new refreshing and valuable theory to the leadership literature.

\section{Overall impression and conclusion}

Although the book covers 56 chapters and a variety of themes that are at first sight quite overwhelming, each chapter is concise and well written. The chapters fit logically into the strategic leadership value chain framework. Each chapter brings essential information and perspectives, helping the reader understand the complexities and rich nuances and challenges associated with the concept of leadership. The scholarship is sound. The chapters are written by prominent and respected subject matter experts, individuals who are acknowledged as leaders in their domain and practitioners specialising in leadership. As such, each of these 'voices' brings a fresh, authentic and interesting perspective on wellknown leadership themes.

The limitation of the book lies in its lack of contributions in Section 6 and Section 9 on the measurement of leadership. The measurement of leadership in emerging countries contexts is contentious, and more research and evidencebased practice are called for. Although one would not regard the book as breaking new ground, the chapter contributions are generally based on sound conceptual foundations and experiential (real-life) and research-based knowledge from practice. As such, the chapter contributions provide theoryinformed practice about leadership that translates into 'actionable knowledge' (Veldsman \& Johnson, 2016, p. 1). The themes and provocative reasoning presented by the book are also thought stimulating that may well facilitate future research initiatives.

To conclude, 'Leadership: Perspectives from the Front Line' serves as an excellent and robust compendium on leaders and leadership for continuous consulting and referral by corporate leaders (executives and managers), practitioners and leadership specialists in the field, academics and postgraduate students in the global and Africanised multiculturally organisational setting. The hands-on, applied manner in which the book is written makes it accessible for the professional, specialist reader and the postgraduate student. In the academic context, the book presents new knowledge and insights that translate into novel theory especially welcomed in the Africanised scholarly community. The book is a valuable contribution to the curriculum of business schools and postgraduate students who specialise in organisational and leadership psychology, behaviour and practice in emerging country settings. The book definitely fills a gap in the current leadership literature, is a must-read for leaders and practitioners and is generally an excellent book to become familiar with.

\section{Reference}

Veldsman, T.H., \& Johnson, A.J. (2016). Leadership: Perspectives from the Front Line. Randburg, Johannesburg: KR Publishing. 